\title{
Changes on carbohydrates and protein content in North Sulawesi local rice during storage
}

\author{
Y.Y.E. Oessoe ${ }^{1}$, R. Maramis ${ }^{2}$, O.O.J. Warouw ${ }^{2}$, L. C. Mandey ${ }^{2}$ \\ ${ }^{1}$ Doctoral program in Enthomology, Graduate Program, Sam Ratulangi University, Bahu Manado 95115, North \\ Sulawesi, Indonesia \\ ${ }^{2}$ Faculty of Agriculture, Sam Ratulangi University, Bahu Manado 95115, North Sulawesi, Indonesia
}

\begin{abstract}
This study aims at determining changes in the level of carbohydrates and protein during the storage process. The results show that during six-month storage, there are decreases in the levels of carbohydrates and protein content in rice grains. Decreased levels of carbohydrate occurred on red rice obtained from Manado Bersehati market (52.23\%), followed by red rice from Karombosan market (41.21\%). Control rice with insects and fungi protection treatments' experienced the smallest level of carbohydrate decrease (9.20\%). The largest protein content decreased occurred in red rice obtained from Bersehati Market (5,45\%), followed by red rice from Karombasan market (4.93\%). The smallest decrease occurred in the control rice Superwin obtained from Market Bersehati $(0.96 \%)$. Long period storage affects the quality of rice.
\end{abstract}

Keywords: Carbohydrate, protein, rice storage, food quality

\section{INTRODUCTION}

Rice is the important food of the world. Asia ranks number one in terms of rice consumption in the world with an average consumption reaches $30 \%$ of the total food staples. Three countries with the largest consumption of rice in Asia are Bangladesh, Laos, and Indonesia. Rice is a commodity that affects social, economic and politics aspects of a country or region [1]. Recently, the global rice crisis has led to serious discussion because rice is one of the world's major food sources [2]. Rice has high nutrient contents because it contains macromolecular compounds such as carbohydrates, proteins, fats, vitamins, and some minerals. Carbohydrates and proteins are the largest components constitute the endosperm of rice [1] [3].

Rice post-harvest storage is one of the crucial problems faced by many countries. Rice as food must possess in proper techniques and conditions to make it suitable for consumption. According to the Indonesian government standards, consumable rice must have these following general requirements: 1) it is free from pests and diseases, 2) it does not smell bad, 3) it is free from a mixture of bran or husks, and 4) it is free from chemical contents that may harm consumers [4]. Rice may experience a loss of quality during storage. The quality may involve milling quality and the aroma of rice [5]. In general, rice will undergo changes after harvest and during storage [6]. Changes on rice grains during storage may be caused by pests and diseases that exist in the barn. It is commonly encompasses insects and fungi. Insects attack on rice can damage the quality of rice. Insects that attack rice will take some nutrients they need from the rice. Way and Bowling (1991) state that the impact of insect infestation in stored rice grains in the warehouse can cause a loss of about $24-35 \%$ of the rice [7]. Storage, therefore, plays an important role to provide good rice grains.

Rice is the main food sources for the people in North Sulawesi, Indonesia. Rice production in North Sulawesi has increased from year to year. The vertile lands of North Sulawesi lead to the high productions of rice, crops and agricultural product. There are some active volcanous in North Sulawesi regions which contributes to the lands vertility. According to the data, rice production reached 278,261 tonnes in 2007 and increased to 335,204 tonnes in 2011. According to the available data, the level of rice consumption per capita in 2011 reached $139 \mathrm{~kg} / \mathrm{capita}$ [8]. The problems faced in the provision of rice is on the rice grains quality due to long storage in the warehouse.

This study aims at determining the carbohydrate and protein content of various types of rice grains which are circulating in the traditional markets in Manado, North Sulawesi, and knowing the changes on the nutrient content as a result of pests and diseases infestation during storage.

\section{METHODOLOGY}

Materials

Rice grains tested in this study were collected from Bersehati Market, Karombasan Market, and Bahu Market, in Manado North Sulawesi. There were three samples of white rice brands taken from Bersehati Market, namely Sultan, Serang and Ladang, and one variety of red rice. There were two samples of white rice brands taken from Karombasan Market, namely Memberamo and Ladang, and one variety of red rice. There were three 
samples of white rice brands taken from Bahu Market, namely Memberamo, Serang, and PL. As the control group, Superwin brand, which is known to be free from rice pests and diseases, was used.

Equipment used in the study included $500 \mathrm{ml}$ Erlenmeyer flask, volumetric flask, pipette, a set of titration tools, Kjeldhal flask, test tubes, micro pipettes, spatulas, and petri dishes. Materials used were $\mathrm{HCl} 3 \%$, $\mathrm{NaOH} 30 \%, \mathrm{CH}_{3} \mathrm{COOH} 3 \%$, KI $20 \%$, sulfuric acid $25 \%, 0.1 \mathrm{~N}$ Tio solution, 2 gr of a mixture of $25 \mathrm{ml}$ Selenium and As, PP indicator, and boric acid $2 \%$.

\section{Methods}

Rice samples were taken from the three locations and selected markets to obtain samples with the same physical quality and class. Subsequently, the samples were stored for six months, and assessment on protein and carbohydrates was performed periodically every month during the storage period. The procedure to determine the carbohydrates and protein content is as follows:

\section{Determining the Levels of Carbohydrates}

Carbohydrates determination was done by weighing $5 \mathrm{gr}$ of rice and put it in a $500 \mathrm{ml}$ erlenmeyer. After that, $200 \mathrm{ml}$ of $\mathrm{HCl} \mathrm{3 \%}$ solution was added and it was boiled for three hours. After three hours, the solution was cooled and neutralized with a solution of $\mathrm{NaOH} 30 \%$ and $\mathrm{CH}_{3} \mathrm{COOH} 3 \%$ to make the solution slightly acid. The solution was transferred into a $500 \mathrm{ml}$ volumetric flask, and distilled water was added until the volume reaches $500 \mathrm{ml}$. Furthermore, as many as $10 \mathrm{ml}$ of the solution was taken and put into a $500 \mathrm{ml}$ erlenmeyer, and then a solution of Luff School was added as much as $25 \mathrm{ml}$ and $15 \mathrm{ml}$ distilled water. The mixture was then heated on a stable temperaturefor about 3-10 minutes. The solution was further cooled. Once cooled,as much as $15 \mathrm{~mL}$ of $\mathrm{KI} 20 \%$ and of $25 \mathrm{~mL} \mathrm{H}_{2} \mathrm{SO}_{4} 25 \%$ were added. Further, titration was immediately done with $\mathrm{Na}_{2} \mathrm{~S}_{2} \mathrm{O}_{3}$ solution of $0.1 \mathrm{~N}$. The same procedure was done for the blank solution.

\section{Determining Protein Contents}

Protein contents were determined by weighing $0.51 \mathrm{gr}$ of rice and put it in a $100 \mathrm{ml}$ Kjeldhal flask. Then, $2 \mathrm{gr}$ of a mixture of selenium and $25 \mathrm{ml}$ of concentrated sulfuric acid were added. The solution was heated over an electric heater for 2 hours or until it boiled and the solution became greenish and clear. The solution was then allowed to cool, and then the solution was diluted in the flask until it reached the amount of $100 \mathrm{ml}$. Subsequently, $5 \mathrm{ml}$ solution was taken and put into the distiller apparatus (distillation apparatus), and 5 $\mathrm{ml}$ of $\mathrm{NaOH} 30 \%$ and a few drops of PP indicator (phenolphthalein) were added. Distillation was then performed for about 10 minutes, and a solution of the distillate was collected in a vessel containing of $10 \mathrm{ml}$ of $2 \%$ boric acid solution that had been mixed an indicator. The obtained solution was subsequently titrated with $\mathrm{HCl} 0.01 \mathrm{~N}$. The same treatment was also carried out to the blank solution.

\section{Data Analysis}

Glucose level is calculated by the following formula:

$$
\text { Glocose level }=\frac{\mathrm{w} 1 \mathrm{xfp}}{\mathrm{w}} \times 100 \%
$$

Carbohydrate level $=0,90 \times$ glucose level

In which : $\quad$ w1 $=$ sample weight in $\mathrm{mg}$

$\mathrm{W}=$ glucose contained in $\mathrm{ml}$ Tio used in $\mathrm{mg}$ from the list

$\mathrm{fp}=$ dilution factor

Protein content is calculated by the following formula:

$$
\text { Protein content }=\frac{(\mathrm{V} 1-\mathrm{V} 2) \times \mathrm{N} \times 0.014 \times \mathrm{fk} \times \mathrm{fp}}{\mathrm{w}}
$$

In which :

$\mathrm{W}=$ sample weight in gram

$\mathrm{V} 1=$ the volume of $\mathrm{HCl} 0.01 \mathrm{~N}$ used in sample titration

$\mathrm{V} 2=$ the volume of $\mathrm{HCl} 0.01 \mathrm{~N}$ used in blank solution titration

$\mathrm{N}=$ normality of $\mathrm{HCl}$

$\mathrm{fk}=$ conversion factor of protein in general: 6.25 of milk and dairy products

$\mathrm{fp}=$ dilution factor 


\section{Changes in Carbohydrate Levels}

\section{RESULTS AND DISCUSSION}

Carbohydrates as the main macromolecule constituting rice can undergo changes during storage. From the test results of samples several rice varieties originating from several markets in Manado it was known that there has been a decrease in the levels of carbohydrate during the storage process. Decreased levels of carbohydrate of rice taken from Bersehati Market is shown in Table 1.

Table 1.Carbohydrate levels (in \%) of several rice varieties taken from Bersehati Market during storage

\begin{tabular}{|l|l|c|c|c|c|c|c|c|}
\hline \multirow{2}{*}{ No } & \multirow{2}{*}{ Rice Varieties } & \multicolumn{7}{|c|}{ Storage Period (month) } \\
\cline { 3 - 10 } & & 0 & 1 & 2 & 3 & 4 & 5 & 6 \\
\hline 1. & Sultan & 75.35 & 71.85 & 67.39 & 61.95 & 59.45 & 56.80 & 54.67 \\
\hline 2. & Serang & 69.24 & 65.31 & 59.17 & 52.43 & 49.38 & 46.25 & 43.20 \\
\hline 3. & Ladang & 70.82 & 65.22 & 58.10 & 54.05 & 49.90 & 45.81 & 41.62 \\
\hline 4. & Red Rice & 72.68 & 64.55 & 56.05 & 46.95 & 37.15 & 28.75 & 20.45 \\
\hline
\end{tabular}

Each rice variety had different levels of carbohydrates and decreased levels of carbohydrate during storage. The highest percentage of decrease occurred in the carbohydrate content of the red rice variety and the smallest percentage of decrease occurred in Sultan rice variety. At the end of the storage period, the red rice variety experienced a decreased level of carbohydrate by $52.23 \%$, while Sultan rice variety experienced a decreased level of carbohydrate by $20.68 \%$. Decreased levels of carbohydrates in big percentage on the red rice variety may be caused by the activity of insects and other microorganisms in the rice. Data on previous research shows that there are some insects found in red rice variety at the end of the storage period. Enzymes owned by the insects are used to decompose carbohydrates into simpler compounds when insects using rice as a nutritional ingredient.

As changes in the carbohydrate levels of rice varieties from Bersehati Market, the same change also happened to the varieties of rice obtained from Karombasan Market (Table 2).

Table 2. Carbohydrate levels (in \%) of several rice varieties taken from Karombasan Market during storage

\begin{tabular}{|l|l|c|c|c|c|c|c|c|}
\hline \multirow{2}{*}{ No } & \multirow{2}{*}{ Rice varieties } & \multicolumn{7}{|c|}{ Storage period (month) } \\
\cline { 3 - 9 } & & 0 & 1 & 2 & 3 & 4 & 5 & 6 \\
\hline 1. & Membramo & 66.83 & 61.75 & 55.60 & 48.24 & 44.13 & 40.30 & 36.45 \\
\hline 2. & Ladang & 71.52 & 66.40 & 61.95 & 55.75 & 52.61 & 49.47 & 46.32 \\
\hline 3. & Red Rice & 73.46 & 67.25 & 60.75 & 53.65 & 45.85 & 38.95 & 32.25 \\
\hline
\end{tabular}

At the beginning of storage period, red rice variety had the highest carbohydrate content, but at the end of storage period, red rice variety had the lowest carbohydrate content. The largest decrease in carbohydrate levels was experienced by the red rice, that was $41.21 \%$, followed by Membramo rice variety as much as 30.38 $\%$, and the smallest carbohydrate decrease was experienced by Ladang rice variety as much as $25.20 \%$. High carbohydrate content of red rice variety seems to support the development of insects. Insects survived by using grains of rice as nutrition source. The grains became a source of carbohydrates for insects.

Ladang variety experienced the smallest decrease of carbohydrate levels. This was due to low activities and growth of insects during storage compared to Membramo rice and red rice variety. The low activities and growth of insects can be caused by low water levels of Ladang variety and the less number of insects at the beginning of storage than the number of insects on Membramo rice and red rice. According to Pingale et al. (1957), insect infestation in grains is a common problem during rice storage [9].

Table 3. Carbohydrate levels (in \%) of several rice varieties taken from Bahu Market during storage

\begin{tabular}{|l|l|c|c|c|c|c|c|c|}
\hline \multirow{2}{*}{ No } & \multirow{2}{*}{ Rice varieties } & \multicolumn{6}{|c|}{ Storage period (month) } \\
\cline { 3 - 9 } & & 0 & 1 & 2 & 3 & 4 & 5 & 6 \\
\hline 1. & Serang & 68.30 & 65.20 & 60.58 & 53.65 & 50.49 & 47.44 & 44.25 \\
\hline 2. & Membramo & 67.75 & 62.51 & 57.70 & 51.93 & 47.38 & 42.95 & 38.39 \\
\hline 3. & PL & 70.29 & 66.14 & 60.89 & 55.09 & 52.49 & 49.86 & 47.76 \\
\hline
\end{tabular}

Table 3 shows different carbohydrate levels on varieties of rice, namely Serang, Membramo, and PL. Based on the calculation, the difference between the carbohydrate levels at the beginning and at the end of storage period, it was found out that the highest carbohydrate decrease was experienced by Membramo rice, as much as $29.36 \%$, and the lowest carbohydrate decrease was experienced by $P L$ rice, as much as $22.53 \%$.

As a comparison on the effect of insect infestation on grains, the analysis conducted on the control rice, Supewin variety, it was found out that the carbohydrate decrease experienced by this variety was better than other varieties (Table 4). 
Table 4. Carbohydrate levels(in \%) of Superwin rice variety during storage

\begin{tabular}{|c|c|c|c|c|c|c|c|c|}
\hline \multirow{2}{*}{ No } & \multirow{2}{*}{ Rice Variety } & \multicolumn{6}{|c|}{ Storage Period (month) } \\
\cline { 3 - 10 } & & 0 & 1 & 2 & 3 & 4 & 5 & 6 \\
\hline 1. & Superwin & 77.15 & 74.32 & 72.40 & 70.65 & 69.30 & 68.45 & 67.95 \\
\hline
\end{tabular}

At the end of the storage period, Superwin variety, which is known to be free from insects, experienced a very small decrease in carbohydrate levels, as much as $9.2 \%$. This figure is much smaller compared to the percentage of decrease on carbohydrate levels, as the other varieties are not free from insects since the beginning of storage. This means that insect activities on grains in storage affect much on the decrease of carbohydrate levels. Without the existence of insects of rice grains, changes on carbohydrate levels can be minimized.

Previous research on carbohydrate content in rice grains has been carried out and is interesting to study because the majority of rice grain is composed of carbohydrates. Rice contains about $90 \%$ carbohydrate [10]. All types of rice experience decreased carbohydrate levels during storage. Percentage of decreased carbohydrate levels of each type of rice at the end of storage (month $6^{\text {th }}$ ) is shown in Table 5.

Table 5. Carbohydrate levels (on \%) at the end of storage periods

\begin{tabular}{|c|c|c|c|c|c|}
\hline No & Market & Rice Variety & $\begin{array}{c}\text { Initial Carbohydrate Levels } \\
\text { (month 0) } \\
(\%)\end{array}$ & $\begin{array}{l}\text { Final Carbohydrate } \\
\text { Level (month 6) (\%) }\end{array}$ & $\begin{array}{c}\text { Decrease in Carbohydrate } \\
\text { Levels }(\%)\end{array}$ \\
\hline 1. & Bersehati & $\begin{array}{l}\text { Sultan } \\
\text { Serang } \\
\text { Ladang } \\
\text { Red rice }\end{array}$ & $\begin{array}{l}75.35 \\
69.24 \\
70.82 \\
72.68\end{array}$ & $\begin{array}{l}54.67 \\
43.20 \\
41.62 \\
20.45\end{array}$ & $\begin{array}{l}\mathbf{2 0 . 6 8 \%} \% \\
26.04 \% \\
29.20 \% \\
\mathbf{5 2 . 2 3 \%}\end{array}$ \\
\hline 2. & $\begin{array}{l}\text { Karomba } \\
\text { san }\end{array}$ & $\begin{array}{l}\text { Membramo } \\
\text { Ladang } \\
\text { Red rice }\end{array}$ & $\begin{array}{l}66.83 \\
71.52 \\
73.46\end{array}$ & $\begin{array}{l}36.45 \\
46.32 \\
32.25\end{array}$ & $\begin{array}{l}30.38 \% \\
25.20 \% \\
\mathbf{4 1 . 2 1 \%}\end{array}$ \\
\hline 3. & Bahu & $\begin{array}{l}\text { Serang } \\
\text { Membramo } \\
\text { PL }\end{array}$ & $\begin{array}{l}68.30 \\
67.75 \\
70.29\end{array}$ & $\begin{array}{l}44.25 \\
38.39 \\
47.76 \\
\end{array}$ & $\begin{array}{l}24.05 \% \\
29.36 \% \\
22.53 \%\end{array}$ \\
\hline 4. & Bersehati & $\begin{array}{l}\text { Superwin } \\
\text { (control ) }\end{array}$ & 77.15 & 67.95 & $9.20 \%$ \\
\hline
\end{tabular}

Long time rice storage can affect the physical, chemical and functional quality of rice. Carbohydrates will experience changes leading to damage. The aleurone of rice is more susceptible to damage compared to the endosperm. Degradation of carbohydrates into $\mathrm{CO}_{2}$ during the storage process usually happens very slowly, except when the humidity reaches $14 \%$ [11]. In the period of 3-4 weeks after harvest, rice may change its properties, especially at the temperature above $15^{\circ} \mathrm{C}$. Rice aroma may be lost and may be lowered [12]. Fungi are known as one of the causes of damaged rice during storage. Tipples (1995) states the primary fungi which attack rice are Aspergillus and Penicillium [13]. Humidity, temperature, and retention time are the factors that influence fungal attack against rice grains stored in a warehouse [14]. Keeping rice dry during storage is one of the simplest ways to maintain the quality of rice.

\section{Changes in Protein Levels}

Protein found in rice grains and become the important components of in rice grains. Protein in rice grains can reach $10 \%$ of total rice weight. Based on the laboratories assessment, there are proteins decreases during rice storage.

Table 6. Protein levels (in \%) of several rice varieties taken from Bersehati Market during storage

\begin{tabular}{|l|l|c|c|c|c|c|c|c|}
\hline \multirow{2}{*}{ No } & \multirow{2}{*}{ Rice Varieties } & \multicolumn{9}{|c|}{ Storage Period (month) } \\
\cline { 3 - 10 } & & 0 & 1 & 2 & 3 & 4 & 5 & 6 \\
\hline 1. & Sultan & 5.78 & 5.45 & 4.94 & 4.67 & 4.39 & 4.10 & 3.88 \\
\hline 2. & Serang & 5.90 & 5.42 & 4.77 & 4.46 & 4.18 & 3.92 & 3.69 \\
\hline 3. & Ladang & 5.23 & 4.81 & 4.25 & 3.87 & 3.50 & 3.15 & 2.75 \\
\hline 4. & Red rice & 10.69 & 9.84 & 8.67 & 7.72 & 6.86 & 6.02 & 5.24 \\
\hline
\end{tabular}

Red rice is a rice variety with high protein content. Of the ten varieties of red rice that have been tested previously by Sompong et al. (2011), it has been found out that the protein contents of red rice range from 7.16 to 10.36 [15]. Each type of rice experiences protein content decreased during storage. The largest decrease on protein contents was experienced by the red rice which was $5.45 \%$, while the smallest decline was experienced by Sultan rice as much as $1.90 \%$. Red rice that has greater protein content than other varieties of rice experienced the highest decrease on protein content (Table 6). This is due to the high protein content in red rice, 
which becomes good nutrition source for the growth and proliferation of insects. Protein is an indispensable building block needed by insects.

Table 7. Protein levels (in \%) of several rice varieties taken from Karombasan Market during storage

\begin{tabular}{|l|l|c|c|c|c|c|c|c|}
\hline \multirow{2}{*}{ No } & \multirow{2}{*}{ Rice Varieties } & \multicolumn{7}{|c|}{ Storage Period (month) } \\
\cline { 3 - 9 } & & 0 & 1 & 2 & 3 & 4 & 5 & 6 \\
\hline 1. & Membramo & 6,38 & 5,98 & 5,35 & 4,76 & 4,38 & 3,98 & 3,65 \\
\hline 2. & Ladang & 4,93 & 4,55 & 3,80 & 3,52 & 3,19 & 2,85 & 2,51 \\
\hline 3. & Red rice & 9,25 & 8,53 & 7,43 & 6,63 & 5,88 & 5,10 & 4,32 \\
\hline
\end{tabular}

Differences on the existing values of protein content in Table 7-8 also shows a decrease in the protein content of rice with increasing storage time. The largest decline on protein contents was experienced by red rice, while Membramo variety experienced the smallest decline. Based on the differences between the initial protein content (month 0) and the final protein content (month $6^{\text {th }}$ ), red rice experienced $4.93 \%$ decrease on protein content, while Membramo experienced $2.73 \%$ decrease on protein content.

Table 8. Protein levels (in \%) of several rice varieties taken from Bahu Market during storage

\begin{tabular}{|l|l|l|l|l|l|l|l|l|}
\hline \multirow{2}{*}{ No } & \multirow{2}{*}{ Rice Varieties } & \multicolumn{6}{|c|}{ Storage Period (month) } \\
\cline { 3 - 10 } & & 0 & 1 & 2 & 3 & 4 & 5 & 6 \\
\hline 1. & Serang & 6,04 & 5,65 & 5,13 & 4,83 & 4,50 & 4,21 & 3,90 \\
\hline 2. & Membramo & 6,65 & 6,20 & 5,57 & 5,17 & 4,79 & 4,40 & 4,04 \\
\hline 3. & PL & 5,07 & 4,81 & 4,36 & 3,98 & 3,65 & 3,30 & 3,02 \\
\hline
\end{tabular}

The protein contents of each type of rice steadily decreased since the initial month storage until the end of storage. The decreased levels of protein content in each type of rice were different. The highest decreased level was experienced by Membramo variety, as much as $2.61 \%$, from $6.65 \%$ to $4.04 \%$. PL variety experienced decreased protein content as much as $2.05 \%$, which became the smallest. Meanwhile, rice control (Superwin rice grains without insect) experienced the smallest deceased protein levels (Table 9). The protein contents of Superwin variety, even if it does not contain insects, also decreased with the time of storage.

Table 9. Protein content in Superwin rice.

\begin{tabular}{|l|l|c|c|c|c|c|c|c|}
\hline \multirow{2}{*}{ No } & \multirow{2}{*}{ Rice Varieties } & \multicolumn{7}{|c|}{ Storage Period (month) } \\
\cline { 3 - 8 } & & 0 & 1 & 2 & 3 & 4 & 5 & 6 \\
\hline 1. & Superwin & 6,25 & 6,09 & 5,80 & 5,55 & 5,43 & 5,35 & 5,29 \\
\hline
\end{tabular}

Based on the data in Table 6, 7 and 8, the white rice varieties in three markets in Manado have protein contents range from $4.90 \%-6.65 \%$. Kennedy and Burlingame (2003) previously report that the ranges of rice protein in Asia are between 4.50\% - $15.9 \%$ [16]. The average protein content of rice is Asia is 8.7\%. Compared with the data, the rice varieties from the markets in Manado contain lower protein. All varieties of rice from the three locations were stored for 6 months and they experienced decreased protein levels. At the beginning and end of storage, red rice from Bersehati Market has the highest protein content of $10.69 \%$ and 5.24\%. At the beginning and end of storage periods, Ladang variety from Karombasan Market had the lowest protein content, which was $4.93 \%$ and $2.51 \%$. Decreased levels of protein content from each of the three varieties of rice taken from the markets are clearly described in Table 10.

Table 10. Percentage of protein decrease of rice grains in North Sulawesi market.

\begin{tabular}{|c|c|c|c|c|c|}
\hline No & Market & Rice Variety & $\begin{array}{c}\text { Initial Protein } \\
\text { Levels } \\
\text { (month 0) } \\
(\%)\end{array}$ & $\begin{array}{l}\text { Final Protein Level } \\
\quad(\text { month 6) }(\%)\end{array}$ & $\begin{array}{l}\text { Decrease in Protein } \\
\text { Levels }(\%)\end{array}$ \\
\hline 1. & Bersehati & $\begin{array}{l}\text { Sultan } \\
\text { Serang } \\
\text { Ladang } \\
\text { Red rice } \\
\end{array}$ & $\begin{array}{c}5.78 \\
5.90 \\
5.23 \\
10.69 \\
\end{array}$ & $\begin{array}{l}3.88 \\
3.69 \\
2.75 \\
5.24 \\
\end{array}$ & $\begin{array}{l}\mathbf{1 . 9 0} \% \\
2.21 \% \\
2.48 \% \\
\mathbf{5 . 4 5 \%} \\
\end{array}$ \\
\hline 2. & Karombasan & $\begin{array}{l}\text { Membramo } \\
\text { Ladang } \\
\text { Red rice }\end{array}$ & $\begin{array}{l}6.38 \\
4.93 \\
9.25 \\
\end{array}$ & $\begin{array}{l}3.65 \\
2.51 \\
4.32 \\
\end{array}$ & $\begin{array}{l}2.73 \% \\
2.42 \% \\
\mathbf{4 . 9 3 \%}\end{array}$ \\
\hline 3. & Bahu & $\begin{array}{l}\text { Serang } \\
\text { Membramo } \\
\text { PL }\end{array}$ & $\begin{array}{l}6.04 \\
6.65 \\
5.07 \\
\end{array}$ & $\begin{array}{l}3.90 \\
4.04 \\
3.02 \\
\end{array}$ & $\begin{array}{l}2.14 \% \\
2.61 \% \\
2.05 \%\end{array}$ \\
\hline 4. & Bersehati & $\begin{array}{l}\text { Superwin } \\
\text { (control) }\end{array}$ & 6.25 & 5.29 & $0.96 \%$ \\
\hline
\end{tabular}


Sultan variety experienced the smallest changes in protein content characterizing low activities and proliferation of insects. It is also influenced by the condition of the rice having low enough moisture content that is only $12.15 \%$. Protein in rice is often concentrated in the outer layer than in the inner layer. Martin and Fitzgerald (2002) state the major protein in rice is Oryzenin [10]. In addition, as in other cereals group, a protein found in rice prolamin include, among others, Glubolin and albumin. Marshal and Wadsworth (1994) report during the storage protein contents do not change much. Changes often occur on the physicochemical properties of the protein [11].

Providing good quality of grain rice is important issues in North Sulawesi. In North Sulawesi, rice grain quality is heavily influenced by length of rice storage in warehouse. Length periods of rice grain storage in warehouse are usually motivated by the economic and distribution circulation administration. In such a case, the local and provincial governments should take into consideration several fundamental regulations aspects of rice storage management and market circulation.

\section{CONCLUSION}

During storage, the levels of carbohydrates in every variety of rice decreased. The highest decreased level of carbohydrate was experienced by red rice variety from Bersehati Market as much as 52.53\%. The protein contents of each type of rice decreased during storage. Red rice from Bersehati Market experienced the highest decreased protein content, which was $5.45 \%$.

\section{Acknowledgements}

The authors wish to thank Rector of the University of Sam Ratulangi, Manado and Director of Graduate Program, Sam Ratulangi University.

\section{REFERENCES}

[1] FAO, Rice and Human Nutrition (Food and Agriculture Organization of the United Nations, VialedelleTerme di Caracalla, Rome 00100, Italy, 2004).

[2] P. Timmer, Food security in Indonesia: current challenges and the long-run outlook. Center For Global Development Working Paper, 2004.

[3] AP. Resurrection, BO. Juliano and Y. Tanaka, Nutrient content and distribution in milling fractions of rice grain. Journal of the Science of Food and Agriculture, 30(5), 1979, 475-481.

[4] Badan Standardisasi Nasional. StandarNasional Indonesia Beras Giling. SNI 6128:2008. Badan Standardisasi, Jakarta, 2008.

[5] S. Wongpornchai, K. Dumri, S. Jongkaewwattana and B. Siri, Effects of drying methods and storage time on the aroma and milling quality of rice (Oryzasativa L.) cv. KhaoDawk Mali 105. Food chemistry, 87(3), 2004, 407-414.

[6] Z. Zhou, K. Robards, S. Helliwell and C. Blanchard, Ageing of stored rice: changes in chemical and physical attributes. Journal of Cereal Science, 35(1), 2002, 65-78

[7] MO. Way and CC, Bowling, Insect pests of rice. In MO. Way and CC. Bowling (eds), Rice (Springer US, 1991) 237-268.

[8] BPS Sulut, Sulawesi Utara dalam Angka Tahun1996 -2012 (BadanPusat Statistik Provinsi Sulawesi Utara, Manado, 2013).

[9] SV. Pingale, SB. Kadkol, MN. Rao, M. Swaminathan and V. Subrahmanyan, Effect of insect infestation on stored grain. II.studies on husked, hand-pounded and milled raw rice, and parboiled milled rice. Journal of the Science of Food and Agriculture, $8(9), 1957,512-516$

[10] M. Martin and MA. Fitzgerald, Proteins in rice grains influence cooking properties!, Journal of Cereal Science, 36(3), 2002, 285294.

[11] WE. Marshal and JI. Wadsworth, Rice: Science and Technology (Marcel Dekker, Inc., New York, 1994).

[12] BO. Juliao, The chemical basis of rice grain quality. Proceeding of the Workshop on Chemical Aspect of Rice Grain Quality, International Rice Research Institute, Los Banos, Laguna, Philiphines, 1979.

[13] KH. Tipples, Quality and nutritional changes in stored grain, Stored Grain Ecosystems, (1995) 325-351.

[14]. CM. Christensen, Deterioration of stored grains by fungi. The Botanical Review, 23(2), 1957, 108-134.

[15] R. Sompong, S. Siebenhandl-Ehn, G. Linsberger-Martin and E. Berghofer, , Physicochemical and antioxidative properties of red and black rice varieties from Thailand, China and Sri Lanka. Food Chemistry, 124(1), 2011, 132-140.

[16] G. Kennedy and B. Burlingame, Analysis of food composition data on rice from a plant genetic resources perspective. Food Chemistry, 80(4), 2003, 589-596. 